\title{
Pengembangan Instrumen Penilaian Tematik di Sekolah Dasar
}

\author{
Sumaryanta dan Estina Ekawati \\ PPPPTK Matematika, Sleman, DIY
}

\begin{abstract}
Assessment on thematic learning in primary schools has far been using partial assessment per subject which is not aligned with the basic concepts of thematic learning that are integrated and holistic. The purpose of this study is to develop thematic test instruments for the assessment of learning in primary schools that are appropriate for thematic learning. This research is a research development. The development phase of the test in this study includes: test planning, test trials, determining the validity of the test, and determining the reliability of the test. The product sample respondents in this study were 111 primary school students of Special Region of Yogyakarta and Central Java. The test results were then analyzed, including: the level of difficulty, different power, validity, reliability, and interpretation of the test. Based on the results of the analysis, this research produced thematic test instruments with the following characteristics: (1) Questions were not made for each subject but at the same time measuring the achievement of basic competencies of several subjects, and (2) Questions using thematic stimulus initiated questions that meet the needs of basic competency measurement.
\end{abstract}

Keywords: assessment, test, thematic

\section{A. Pendahuluan}

Pembelajaran Tematik Terpadu merupakan suatu pendekatan dalam pembelajaran yang secara sengaja mengaitkan beberapa aspek baik dalam intra mata pelajaran maupun antar mata pelajaran. Dengan adanya pemaduan itu, peserta didik akan memperoleh pengetahuan dan keterampilan secara utuh sehingga pembelajaran menjadi bermakna bagi peserta didik. Bermakna dalam pengertian ini memiliki maksud bahwa dengan model pembelajaran tematik terpadu ini, siswa akan memahami pembelajaran dengan berdasarkan pada pengalaman langsung dan menghubungkannya dengan realita yang ada di lingkungan sekitar.

Pembelajaran tematik berdasar pada filsafat konstruktivisme yang berpandangan

bahwa pengetahuan yang dimiliki peserta didik merupakan hasil bentukan peserta didik sendiri. Peserta didik membentuk pengetahuannya melalui interaksi dengan lingkungan, bukan hasil bentukan orang lain. Secara pedagogis pembelajaran tematik berdasarkan pada eksplorasi terhadap pengetahuan dan nilai-nilai yang dibelajarkan melalui tema sehingga peserta didik memiliki pemahaman yang utuh. Peserta didik diposisikan sebagai pengeksplorasi sehingga mampu menemukan hubungan-hubungan dan pola-pola yang ada di dunia nyata dalam konteks yang relevan.

Hakikat pembelajaran tematik terpadu adalah pembelajaran lintas disiplin yang menghubungkan berbagai gagasan, konsep, keterampilan, sikap, dan nilai, baik antar mata pelajaran maupun dalam satu mata pelajaran. Karakteristik pembelajaran seperti itu menuntut penilaian yang holistik dan menyeluruh. Penilaian merupakan proses pengumpulan dan pengolahan informasi untuk mengukur pencapaian hasil 
belajar peserta didik. Prinsipprinsip penilaian dalam pembelajaran tematik sama dengan prinsip yang harus dijadikan landasan dalam pembelajaran terpadu, yaitu prinsip utuh dan menyeluruh, berkesinambunagn, dan objektif.

Aspek penilaian merupakan salah satu permasalahan yang sampai saat ini masih belum terpecahkan sepenuhnya dalam pembelajaran tematik. Penilaian pada pembelajaran tematik masih dilakukan secara terpisah untuk tiap masing-masing mata pelajaran, sedangkan pembelajarannya telah dilakukan secara tematik. Instrumen yang digunakan guru untuk penilaian dibuat secara masing-masing untuk setiap mata pelajaran. Hal ini tidak selaras dengan konsep dasar pembelajaran tematik yang mengedepankan pada keterpaduan tetapi penilaiannya masih bersifat parsial.

Sistem penilaian merupakan bagian integral yang tidak dapat dipisahkan dari sistem pendidikan matematika sehingga setiap usaha memperbaiki sistem pendidikan matematika tanpa disertai perbaikan sistem penilaian tidak akan dapat memberikan hasil yang optimal, bahkan mungkin akan sia-sia. Setiap metode pendidikan matematika membutuhkan sistem penilaian yang berbeda (Van den Heuvel-Panhuizen, 1996: 99). Setiap upaya melakukan pembaharuan sistem pendidikan harus disertai dengan pembaharuan sistem penilaian (Mardaphi, 2008: 5). Oleh karena itu perlu dikembangkan suatu sistem penilaian tematik yang selaras dengan konsep pembelajaran tematik. Penelitian ini dilakukan dalam rangka mengembangkan model instrumen tes penilaian tematik yang diharapkan dapat mendukung optimalisasi penerapan pembelajaran tematik terpadu di sekolah dasar.

\section{B. Metode Penelitian}

Penelitian ini merupakan penelitian pengembangan untuk mengembangkan mengembangkan instrumen penilaian tematik untuk mendukung pembelajaran tematik terpadu di sekolah dasar. Tahap pengembangan tes dalam penelitian ini meliputi: perencanaan tes, ujicoba tes, penentuan validitas tes, dan penentuan reliabilitas tes.

Teknik pengumpulan data yang digunakan dalam penelitian ini meliputi: studi dokumentasi, Forum Group Design (FGD), dan tes. Studi dokumentasi dilakukan terhadap regulasi yang berkaitan dengan pembelajaran dan penilaian di sekolah dasar. FGD dilakukan untuk melakukan telaah butir soal dengan ahli. Ahli yang dilibatkan dalam telaah tes yang dikembangkan dalam penelitian ini adalah pakar di bidang instrumen, yaitu dosen pada Program Pascasarjana Universitas Negeri Yogyakarta pada Prodi Penelitian dan Evaluasi Pendidikan, dan pakar di bidang pendidikan sekolah dasar, yaitu widyaiswara jenjang sekolah dasar dari PPPPTK Matematika (1 orang), PPPPTK IPA (1 orang), PPPPTK PKn/IPS (1 orang) dan PPPPTK Bahasa (1 orang). Sedangkan tes dilaksanakan pada tahap ujicoba lapangan. Dalam penelitian ini ujicoba dilakukan dengan cara instrumen tes yang telah dikembangkan digunakan di lapangan/kelas. Ujicoba dilaksanakan di 4 (empat) Sekolah Dasar dengan rincian sebagai berikut. 
Tabel 1 Responden ujicoba

\begin{tabular}{llllc}
\hline No & Sekolah & Kabupaten & Propinsi & Jumlah Siswa \\
\hline 1. & SD Kotagede 3 & Kota Yogyakarta & DIY & 32 \\
\hline 2. & SD Ngrukeman & Kota Yogyakarta & DIY & 37 \\
\hline 3. & SD Srumbung 2 & Magelang & Jawa Tengah & 27 \\
\hline 4. & SD Muntilan & Magelang & Jawa Tengah & 32 \\
\hline
\end{tabular}

Data yang diperoleh dari ujicoba selanjutnya dianalisis, meliputi: penentuan tingkat kesukaran, daya beda, validitas konstruk, reliabilitas tes, dan penafsiran hasil tes. Penafsiran indeks kesukaran didasarkan pada ketentuan: $\quad 0,00-0,30$ soal tergolong sukar, $0,31-0,70$ soal tergolong sedang, dan 0,71-1,00 soal tergolong mudah. Penentuan daya beda didasarkan pada ketentuan: $0,40-1,00$ soal diterima/baik, 0,30-0,39 soal diterima tetapi perlu diperbaiki, 0,20-0,29 soal diperbaiki, dan $0,19-0,00$ soal tidak dipakai/dibuang.

Validitas konstruk dalam penelitian ini diuji dengan analisis faktor menggunakan software LISREL. Analisis faktor yang dilakukan dalam pengujian ini adalah Confirmatory Factor Analysis (CFA). Uji pada tahap ini dilakukan untuk mengetahui apakah indikator atau dimensi benar-benar mengukur atau merefleksikan variabel laten yang diuji. Model dikatakan memiliki kecocokan dengan data empirik apabila terpenuhi minimal 3 indikator fit terpenuhi. Uji validitas dilakukan dengan memperhatikan nilai factor loading standard setiap indikator atau dimensi. Apabila nilai factor loading standard $\geq 0.3$ maka dinyatakan valid. Selanjutnya uji statistika $t$ digunakan untuk mengevaluasi signifikansi parameter estimasi. Apabila nilai $t$ berwarna merah maka tidak signifikan, sedangkan apabila nilai $t$ pada output berwarna hitam maka signifikan.
Penentuan reliabilitas dalam penelitian ini menggunakan koefisien Alpha Cronbach yang dihitung dengan program pengolah data SPSS. Kategorisasi reliabilitas model tes kompetensi guru yang dikembangkan dalam penelitian ini menggunakan ketentuan: $0,80<\mathrm{r}_{11} \leq 1,00$ reliabilitas sangat tinggi, $\quad 0,60<\mathrm{r}_{11} \leq 0,80$ reliabilitas tinggi, $\quad 0,40<r_{11} \leq 0,60$ reliabilitas sedang, $0,20<\mathrm{r}_{11} \leq 0,40$ reliabilitas rendah, dan $-1,00<\mathrm{r}_{11} \leq 0,20$ reliabilitas sangat rendah (tidak reliabel).

\section{Hasil Penelitian Pembahasan}

\section{Hasil Penelitian}

Pada tahap awal penyusunan, peneliti menyusun 6 butir soal tematik yang ditujukan untuk mengukur pencapaian kompetensi pada mata pelajaran PKn, Matematika, Bahasa Indonesia, dan PJOK untuk siswa kelas III, khususnya berkaitan dengan tema "Benda di Sekitarku". Setelah ditelaah melibatkan sejumlah pakar dan kemudian direvisi, soal yang disusun kemudian diujicobakan ke responden sebanyak 111 orang siswa sekolah dasar.

Berdasarkan data yang diperoleh dari ujicoba tersebut kemudian dilakukan analisis tingkat kesukaran soal dan daya beda soal. Setelah dilakukan analisis diperoleh hasil yang tersaji pada Tabel 2. 
Tabel 2 Hasil analisis tingkat kesukaran dan data beda soal

\begin{tabular}{lcccc}
\hline \multirow{2}{*}{ No } & \multicolumn{2}{c}{ Tingkat Kesukaran } & & Daya Beda (DB) \\
\cline { 2 - 5 } & TK & Kategori & DB & Kategori \\
\hline $\begin{array}{l}\text { Butir } \\
1\end{array}$ & 0.81 & mudah & 0.13 & Dibuang/diganti \\
\hline $\begin{array}{l}\text { Butir } \\
2\end{array}$ & 0.51 & sedang & 0.31 & diterima dengan revisi \\
\hline $\begin{array}{l}\text { Butir } \\
3\end{array}$ & 0.41 & sedang & 0.5 & diterima tanpa revisi \\
\hline $\begin{array}{l}\text { Butir } \\
4\end{array}$ & 0.24 & sukar & 0.4 & diterima tanpa revisi \\
\hline $\begin{array}{l}\text { Butir } \\
5\end{array}$ & 0.38 & sedang & 0.46 & diterima tanpa revisi \\
\hline $\begin{array}{l}\text { Butir } \\
6\end{array}$ & 0.5 & sedang & 0.46 & diterima tanpa revisi \\
\hline
\end{tabular}

Tabel 2 menunjukkan bahwa dari 6 (enam) butir yang disusun ada 1 (satu) butir termasuk kategori mudah, yaitu butir nomor $1 ; 4$ (empat) butir termasuk kategori sedang, yaitu butir nomor 2, 3, 5, dan 6; dan 1 (satu) butir termasuk kategori sukar. Tabel di atas juga menunjukkan bahwa dari 6 (enam) butir yang disusun, berdasarkan daya bedanya diperoleh bahwa butir nomor 1 harus dibuang atau diganti, butir nomor 2 dapat diterima dengan revisi, dan butir nomor 3, 4, 5, dan 6 dapat diterima tanpa revisi.
Selain untuk menentukan tingkat kesukaran dan daya beda, data hasil ujicoba lapangan juga digunakan untuk menentukan validitas konstruk tes yang dikembangkan dalam penelitian ini. Validitas kontruk tes ditentukan menggunakan analisis faktor, yaitu Confirmatory Factor Analysis (CFA). Proses analisis CFA dalam penelitian ini dilakukan dengan memanfaatkan bantuan program LISREL 8.0.

Setelah mengeluarkan butir soal nomor satu, analisis CFA memberikan output path diagram yang tersaji pada Gambar 1 . 


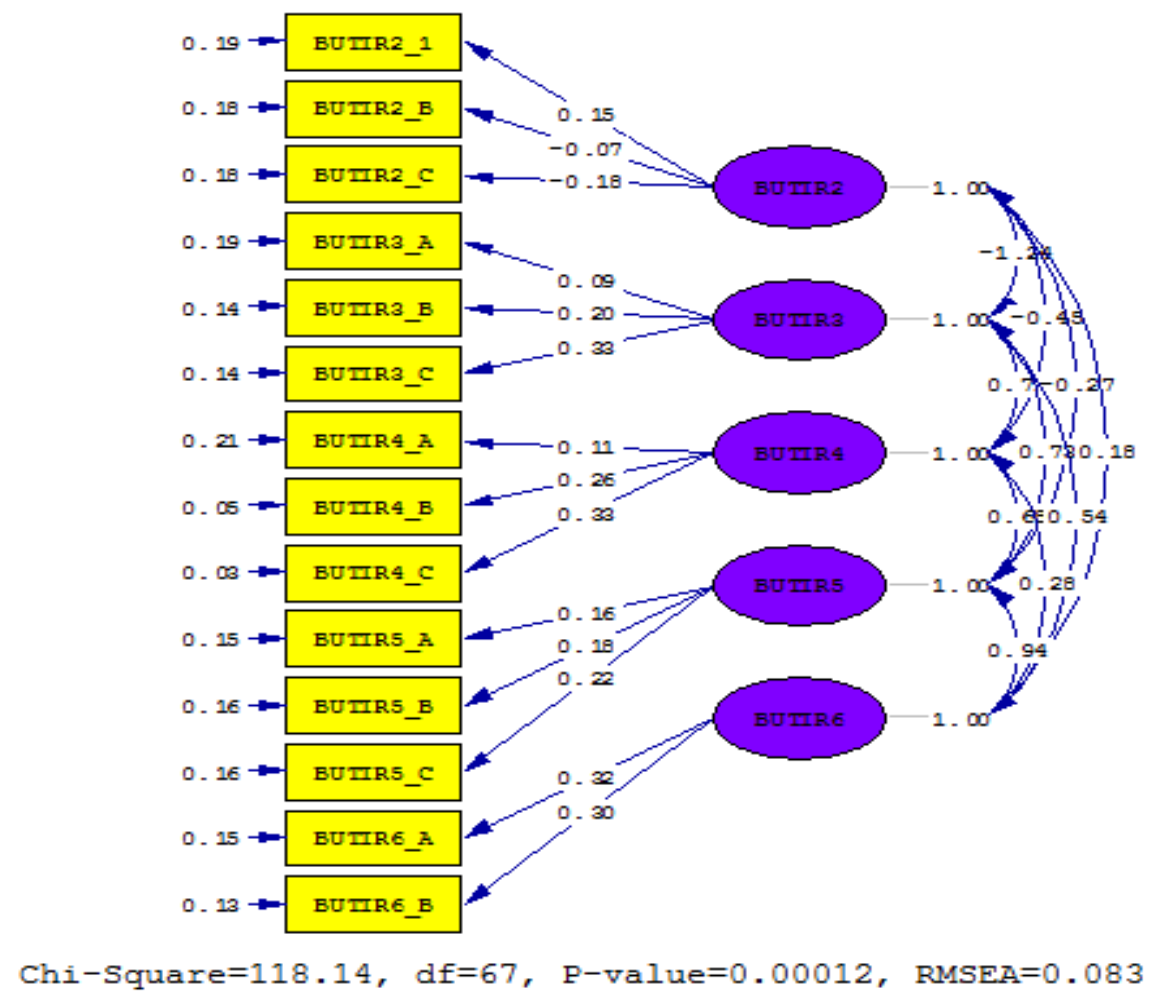

Gambar 1. Output path diagram (standard solution) (modifikasi pertama)

Melihat output pada Gambar 1 , juga memperhatikan output goodness of fit yang lain, diketahui bahwa tidak ada kriteria fit dari model yang terpenuhi. Hal ini menunjukkan bahwa hasil modifikasi pertama yang diperoleh dengan mengeluarkan butir nomor 1 masih menghasilkan model pengukuran yang tidak fit. Oleh karena itu diperlukan modifikasi model pengukuran berikutnya agar diperoleh model pengukuran yang fit.

Modifikasi kedua dilakukan dengan memperhatikan output path diagram hasil modifikasi pertama, dimana pada path diagram tersebut terlihat bahwa loading faktor dari butir 2a, 3a, dan 4a cukup rendah (di bawah 0,30), maka dipertimbangkan untuk mengeluarkan butir-butir tersebut dari analisis. Akan tetapi, untuk butir 4 a peneliti tidak mengeluarkan dengan pertimbangan bahwa apabila butir 4a tersebut dikeluarkan dari analisis (butir soal di buang) akan berdampak butir soal nomor 4 hanya akan mengukur kompetensi untuk mata pelajaran matematika saja, sehingg konsep soal tematik menjadi tidak terpenuhi. Selain itu, peneliti juga mempertimbangkan output path diagram t-value, butir 4a sigifikan memberi kontribusi terhadap butir soal nomor 4. 


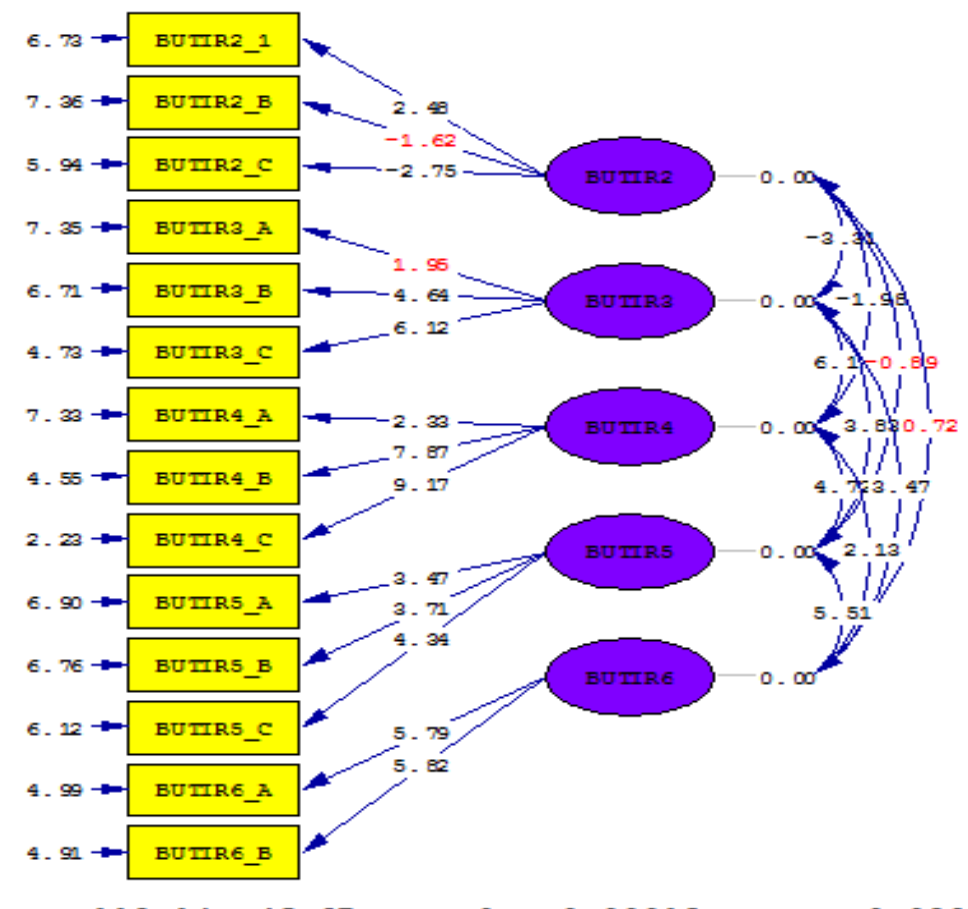

Chi-Square=118.14, df=67, P-value=0.00012, RMSEA=0.083

Gambar 2. Output path diagram (t-values) (modifikasi kedua)

Dari Gambar 2 terlihat bahwa hanya butir $2 \mathrm{~b}$ dan $3 \mathrm{a}$ yang tidak signifikan, ditandai dengan warna merah pada nilai $t$ pada diagram. Dengan pertimbangan tersebut, juga melihat bahwa loading faktor butir 4a masih cukup tinggi (dekat ke 0,30) dan t-value signifikan, maka peneliti memutuskan untuk mempertahankan butir 4a dari analisis.

Setelah mengeluarkan butir $2 \mathrm{~b}$ dan 3a dari analisis, diperoleh output path diagram yang tersaji pada Gambar 3. 


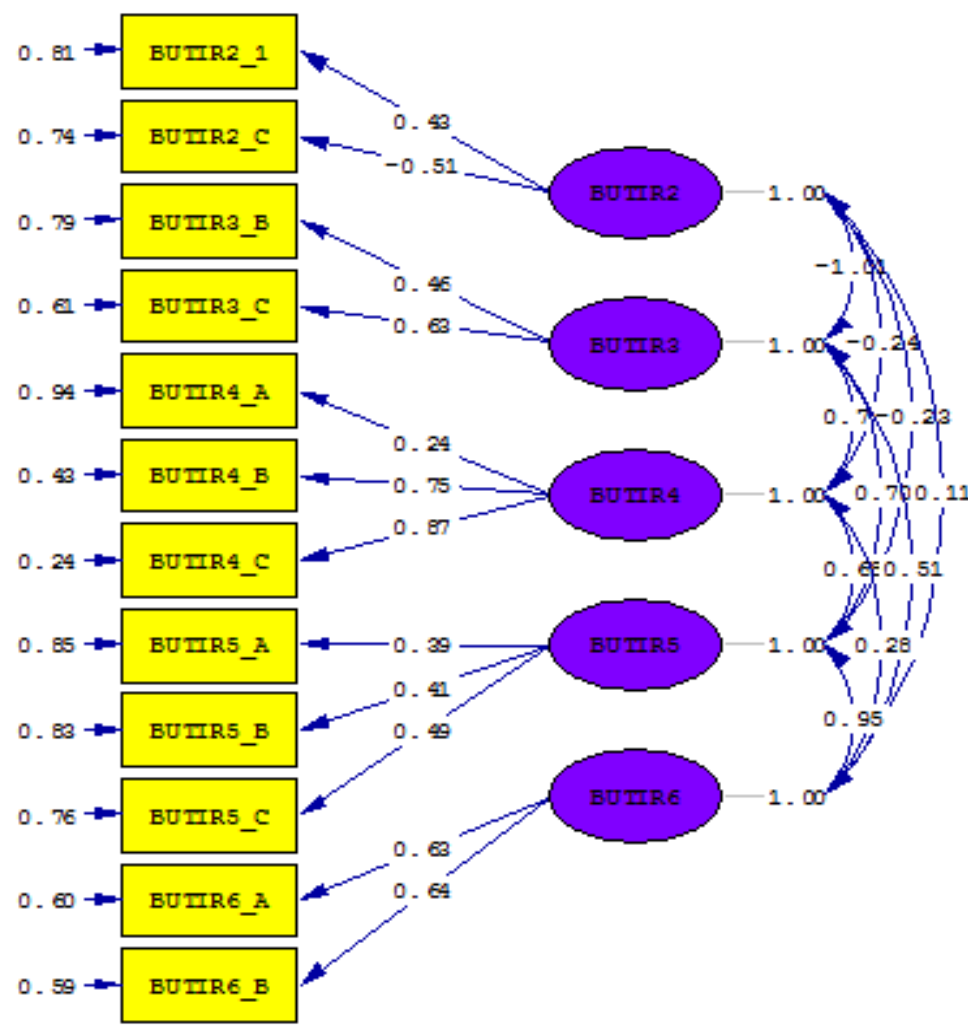

Chi-Square=74.96, df=44, P-value=0.00248, RMSEA $=0.080$

Gambar 3. Output path diagram (standard solution) (modifikasi ketiga)

Dari path diagram pada Gambar 3 diketahui bahwa nilai RMSEA $=0.080$ (memenuhi kriteria fit, yaitu $\leq$ 0.08) dan Chi-Square $=74.96$ (memenuhi kriteria fit $<88$ ). Selain dari path diagram di atas, output LISREL juga memberikan data Goodness of Fit Index (GFI) $=0.90$ memenuhi kriteria fit, yaitu $\geq$ 0.90), dan Normed Chi Square : rasio antara che square dibagi degree of freedom $=1.70$
(Nilai yang disarankan: batas bawah 1.0, batas atas 2.0). Dengan demikian ada 4 (empat) kriteria fit yang terpenuhi. Oleh karena itu dapat disimpulkan bahwa model pengukuran fit didukung data.

Selanjutnya diidentifikasi signifikansi masing-masing butir melalui output t-values yang disajikan pada Gambar 4. 


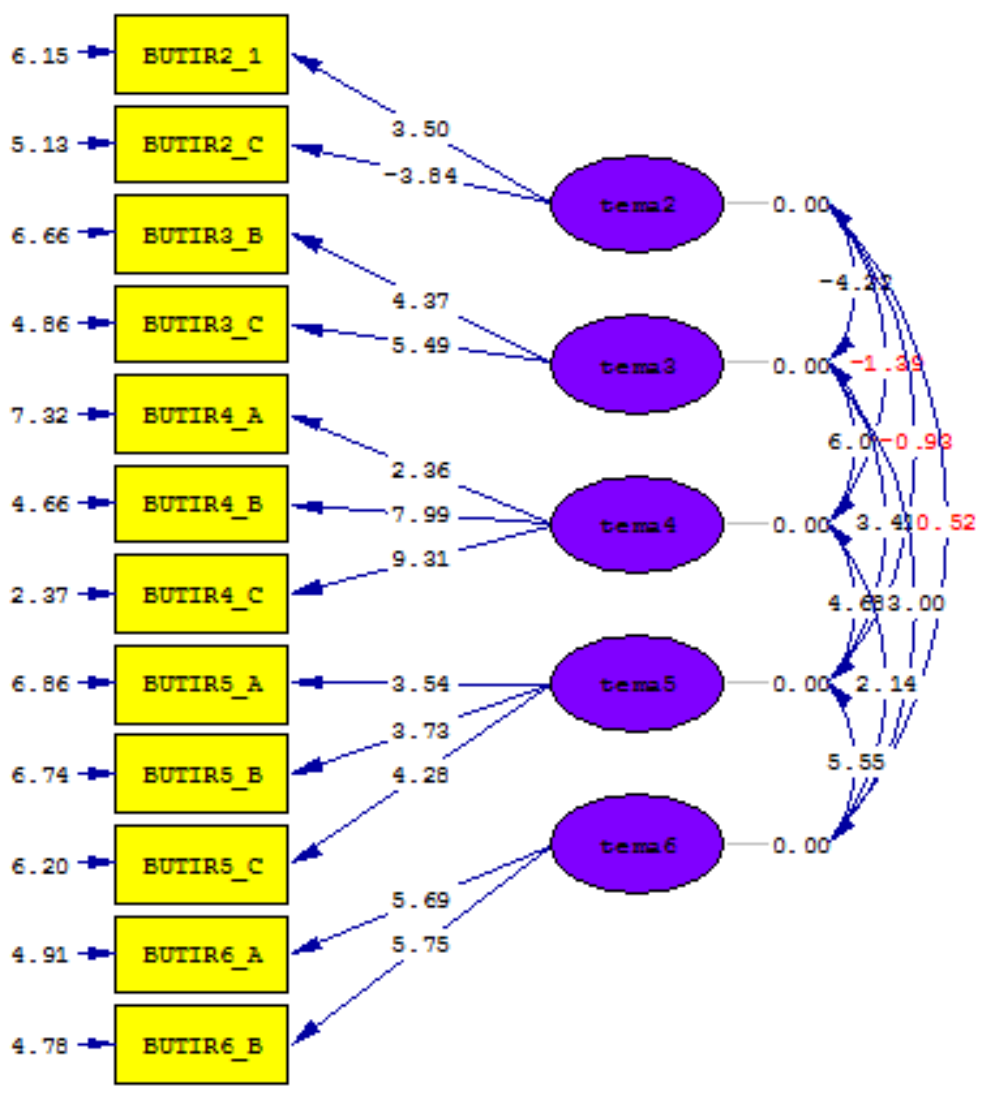

Chi-Square=74.96, df=44, P-value=0.00248, RMSEA=0.080

Gambar 4. Output path diagram ( $t$-values) (modifikasi ketiga)

Dari output t-values di atas dapat disimpulkan bahwa seluruh butir tersebut signifikan terhadap konstruk yang diukur. Dengan demikian butir 2a, 2c, 3b, 3c, 4a, 4b, 4c, $5 a, 5 b, 5 c, \quad 6 a$, dan $6 b$ signifikan mengukur konstruk yang telah ditentukan.

Setelah diperoleh infomasi validitas tes seperti di atas, langkah berikutnya adalah menentukan reliabilitas instrumen. Reliabilitas yang dihitung dalam penelitian ini merupakan reliabilitas tes secara keseluruhan. Hasil perhitungan reliabilitas menggunakan koefisien alpha yang dihitung dengan SPSS diperoleh nilai reliabilitasnya 0.67. Berdasarkan kriteria reliabilitas yang telah disajikan sebelumnya dapat dikatakan bahwa instrumen ini memiliki reliabilitas tinggi.

\section{Pembahasan}

Keselarasan sistem penilaian dengan pembelajaran yang diterapkan merupakan salah satu aspek penting untuk mengoptimalisasikan hasil pembelajaran. Belajar siswa dapat didorong oleh penilaian, dan siswa hanya dapat melakukan hal-hal itu dinilai (Race, 2009: 15). Bahkan penilaian dianggap sebagai mesin yang mengarahkan pembelajaran (Cowan; dalam Race, 2009: 47). Pendapat ini menguatkan pernyataan Boud (1986; dalam Race, 1986: 47) bahwa metode penilaian memiliki pengaruh lebih besar daripada apa dan bagaimana siswa belajar, bahkan 
pengaruh penilaian mungkin lebih penting memberi dampak dibanding materi pembelajaran. Oleh karena itu penting bahwa pendekatan pembelajaran tematik yang diterapkan di sekolah dasar harus disertai dengan sistem dan instrumen penilaian yang bersesuaian.

Kebutuhan

penyesuaian penilaian terhadap

pembelajaran tematik selaras dengan pendapat (Mardapi, 2008) yang menyatakan bahwa setiap upaya pembaharuan sistem pendidikan harus disertai dengan pembaharuan sistem penilaian. Dengan demikian, pembelajaran dengan pendekatan tematik membutuhkan sistem penilaian tematik juga. Hal tersebut senada juga dengan pernyataan Van den HeuvelPanhuizen (1996) yang menyatakan bahwa sistem penilaian merupakan bagian integral yang tidak dapat dipisahkan dari sistem pendidikan matematika sehingga setiap usaha memperbaiki sistem pendidikan tanpa disertai perbaikan sistem penilaian tidak akan dapat memberikan hasil yang optimal, bahkan mungkin akan sia-sia.

Penelitian ini telah menghasilkan instrumen tes tematik yang terdiri dari 5 butir yang selaras dengan pendekatan pembelajaran tematik. Setiap butir mengukur secara simultan lebih dari satu mata pelajaran. Pada setiap soal disajikan suatu stimulus kontekstual tematik yang mana dari masing-masing stimulus tersebut kemudian siswa diberikan pertanyaanpertanyaan yang sesuai dengan kompetensi dasar yang akan diukur. Hal ini selaras dengan konsep dasar pembelajaran tematik dimana pembelajaran tematik merupakan salah satu model pembelajaran terpadu yang menggunakan tema untuk mengaitkan beberapa mata pelajaran sehingga dapat memberikan pengalaman bermakna bagi peserta didik. Model pembelajaran yang dilaksanakan secara terpadu membutuhkan paket penilaian yang terpadu juga.

Instrumen tes tematik yang dihasilkan dalam penelitian ini memberikan contoh model instrumen penilaian tes yang dapat dikembangkan secara tematik yang mengukur kompetensi dasar dari beberapa mata pelajaran secara bersama-sama. Sebagai contoh, butir soal no 5 mengukur kompetensi dasar pada mata pelajaran PKn, Bahasa Indonesia, dan Matematika. Kompetensi dasar yang diukur pada mata pelajaran PKn yaitu KD 4.4 "Menyajikan bentuk-bentuk kebersatuan dalam keberagaman di lingkungan sekitar", kompetensi dasar pada mata pelajaran Bahasa Indonesia, yaitu KD 3.1 "Menggali informasi tentang konsep perubahan wujud benda dalam kehidupan seharihari yang disajikan dalam bentuk lisan, tulis, visual, dan/atau eksplorasi lingkungan", dan kompetensi dasar pada mata pelajaran Matematika yaitu 3.7 "Mendeskripsikan dan menentukan hubungan antar satuan baku untuk panjang, berat, dan waktu yang umumnya digunakan dalam kehidupan sehari-hari". Untuk mengukur KD-KD tersebut diberikan suatu stimulus tentang kerjabakti persiapan HUT RI. Berdasarkan stimulus 
tersebut selanjutnya diberikan beberapa pertanyaan untuk mengukur KD yang akan diukur. Butir-butir soal yang lain juga demikian, yaitu diberikan stimulus dalam suatu tema tertentu kemudian diberikan pertanyaanpertanyaan relevan dengan stimulus tersebut sesuai dengan KD yang akan diukur. Hal demikian selaras dengan pelaksanaan pembelajaran tematik dimana dalam suatu pembelajaran siswa diberikan dalam tema-tema tertentu yang mana berdasarkan tema tersebut kemudian dikembangkan pembelajaran yang diorientasikan untuk mencapai kompetensi yang telah ditetapkan.

Tes tematik yang dihasilkan dalam penelitian ini berbentuk uraian, sebagian urian terbuka dan sebagian uraian yang cenderung seperti isian singkat. Siswa diminta mencari jawaban terhadap pertanyaan yang diberikan berdasarkan stimulus yang diberikan. Tentu bentuk soal tematik dapat dikembangkan dengan beragam bentuk, baik pilihan ganda, isian singkat, uraian terbuka atau yang lain. Variasi bentuk soal tersebut dapat memberikan alternatif yang dapat dipilih guru dalam mengembangkan soal tematik.

\section{Kesimpulan dan Saran}

\section{Kesimpulan}

Berdasarkan hasil penelitian dan pembahasan di atas disimpulkan bahwa penelitian ini telah menghasilkan instrumen tes tematik dengan karakteristik sebagai berikut:

a. Soal tidak dibuat masingmasing untuk setiap mata pelajaran, tetapi satu soal yang memuat sekaligus pertanyaan-pertanyaan

untuk mengukur ketercapaian kompetensi dasar dari beberapa mata pelajaran.

b. Soal menggunakan stimulus tematik, yang kemudian berdasarkan stimulus tersebut diberikan pertanyaan-pertanyaan yang sesuai dengan kebutuhan pengukuran penguasaan kompetensi dasar yang telah ditetapkan.

\section{Saran}

a. Perlu dikembangkan lebih lanjut sistem penilaian tematik, tidak hanya instrumennya tetapi juga meliputi keseluruhan sistem penilaian tematik, termasuk penafsiran hasil dan pelaporannya.

b. Perlu dikembangkan lebih lanjut bentuk-bentuk soal tematik selain bentuk uraian yang telah dihasilkan dari penelitian ini, sehingga guru memiliki lebih banyak altenatif untuk penerapan penilaian tematik di kelas.

c. Penggunaan penilaian tematik perlu dioptimalkan pemanfaatannya untuk mendukung kebijakan dan praktek pembelajaran tematik di sekolah dasar, sehingga terwujud keterpaduan antara pembelajaran dan penilaiannya.

\section{Daftar Pustaka}


Mardapi, D. 2008. Teknik penyusunan instrumen tes dan nontes. Jogyakarta: Mitra Cendikia Offset

Race, P. 2009. Designing assessment to improve physical sciences learning: A physical sciences practice guide. UK: Physical Sciences Centre, Department of Chemistry, University of Hull

Van den Heuvel-Panhuizen. 1996. Assessment and realistic mathematics education. Utrecht: Technipress, Culemborg 